\title{
Pulmonary Hemosiderosis Due to Mitral Valvular Heart Disease
}

Eung Yeop Kim, M.D., Tae Sung Kim, M.D., Joungho Han, M.D. ${ }^{2}$, Kyung Soo Lee, M.D.

We report a case of biopsy-proven secondary hemosiderosis of the lung in a 58-year-old patient with mitral valvular heart disease. Both chest radiography and high-resolution CT demonstrated patchy areas of ground-glass opacity; the former indicated that it was in both lungs, while the latter showed inter- and intralobular septal thickening. These findings were reversible when pulmonary venous hypertension was corrected.

Index words : Mitral valve, regurgitation

Lung, hemorrhage

Lung, CT

In patients with chronic mitral valve disease, repeated bleeding due to pulmonary venous hypertension may result in a hemosiderosis-like picture with organization of the hemorrhage and the appearance of interstitial fibrosis (secondary pulmonary hemosiderosis) $(1-3)$. The reported radiographic findings of secondary pulmonary hemosiderosis are multiple micronodules in both lungs (4). To the best of our knowledge, however, high-resolution (HR) CT findings of pathologically-proven secondary pulmonary hemosiderosis have not been reported. We describe the radiographic and HRCT findings of a case of secondary pulmonary hemosiderosis in a patient with mitral valvular heart disease.

\section{Case Report}

A 58-year-old man presented with cough and dyspnea, which had persisted for a number of years. Chest radiography on admission showed patchy areas of ground-glass opacity in both lower lung zones and septal thickening at the bilateral costophrenic angles

\footnotetext{
'Department of Radiology, Samsung Medical Center, College of Medicine, Sungkyunkwan University

${ }^{2}$ Department of Diagnostic Pathology, Samsung Medical Center, College of Medicine, Sungkyunkwan University Received August 4, 1998; Accepted September 15, 1998

Address reprint requests to: Kyung Soo Lee, M.D., Department of Radiology, Samsung Medical Center, College of Medicine, Sungkyunkwan University

\#50, Ilwon-Dong, Kangnam-Ku, Seoul 135-710, South Korea

Tel. 82-2-3410-2511, Fax. 82-2-3410-2559
}

(Fig. 1A). The heart was slightly enlarged. Because auscultation suggested a possibility of mitral regurgitation, echocardiography and cardiac catheterization were performed. There was a moderate degree of pure mitral regurgitation, a mild degree of tricuspid regurgitation, pulmonary arterial hypertension (systolic pressure/diastolic pressure, $64-\mathrm{mmHg} / 28-\mathrm{mmHg}$; mean, 42-mmHg), increased left atrial pressure of $53-\mathrm{mmHg}$, and left ventricular dysfunction $(50 \%$ of the ejection fraction). Initially, the parenchymal lesions indicated on chest radiographs by groundglass opacity were thought to be due to pulmonary interstitial edema. Because these abnormal opacities persisted, however, HRCT scans of the thorax were obtained ; patchy areas of ground-glass opacity and inter- and intralobular septal thickening were seen in both lower lobes (crazy-paving pattern) (Fig. 1B). The pulmonary lesions seen on CT were thought to be due to chronic interstitial edema or subacute or chronic interstitial lung disease. Transbronchial lung biopsy was performed in the superior and posterior basal segment of the right lower lobe, and this demonstrated interstitial thickening with edema, young fibroblastic proliferation, and type II pneumocyte hyperplasia; these findings suggested the possibility of chronic interstitial lung disease. Lung tissues were subsequently obtained from the superior segment of the right lower lobe during mitral valve replacement. On pathologic examination (Fig. 1C), pulmonary hemosiderosis was 


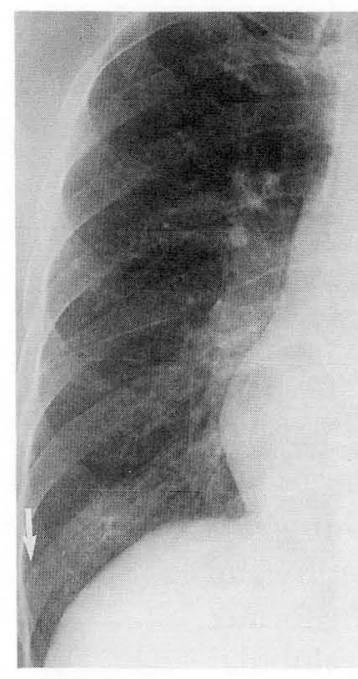

A

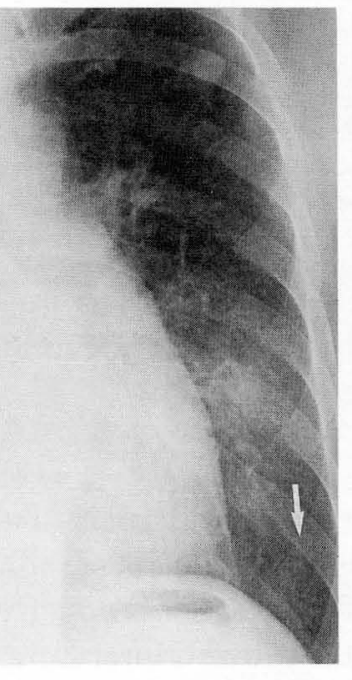

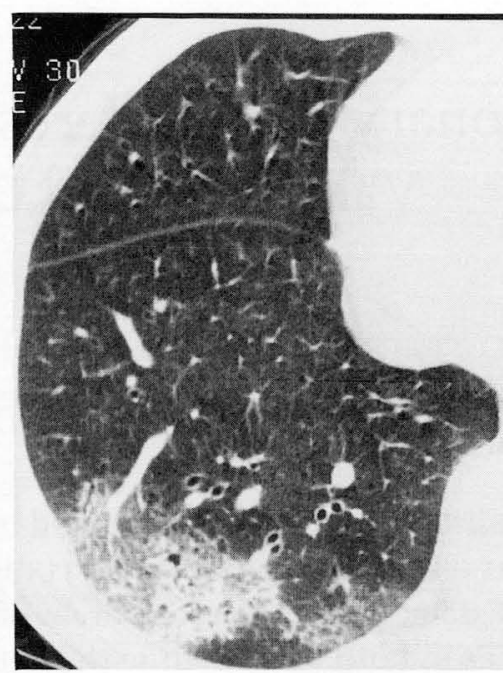

B

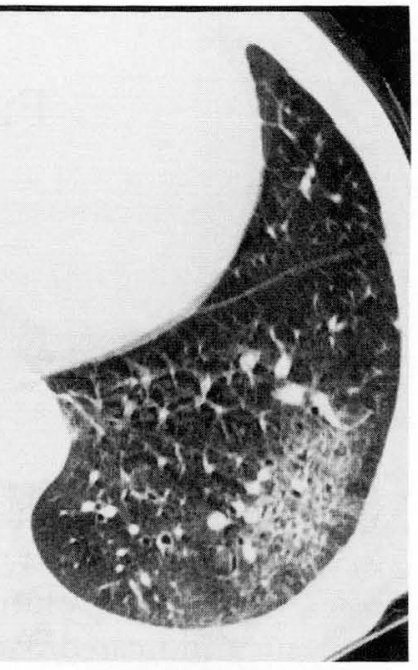

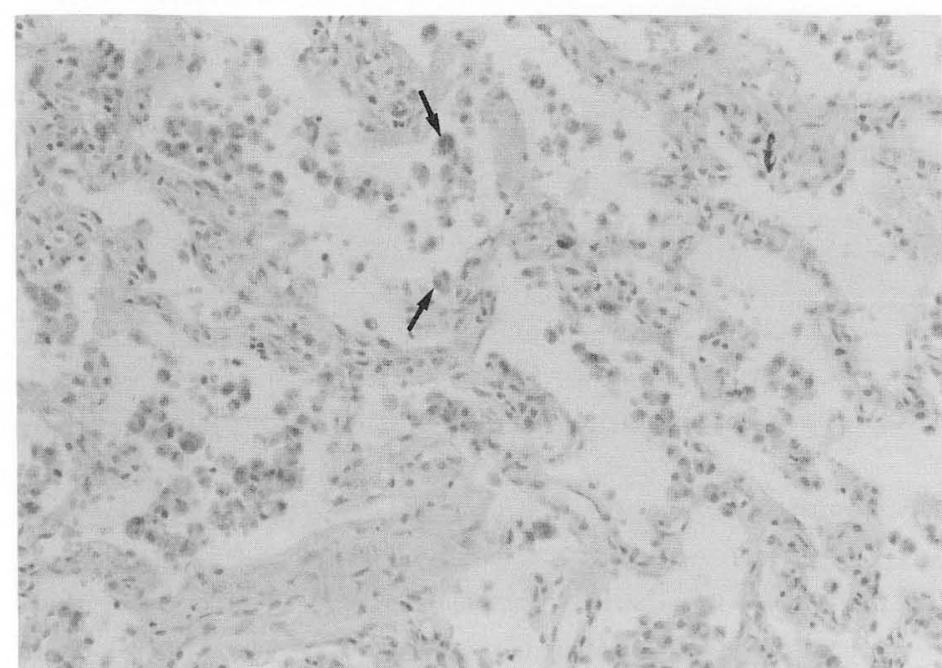

C

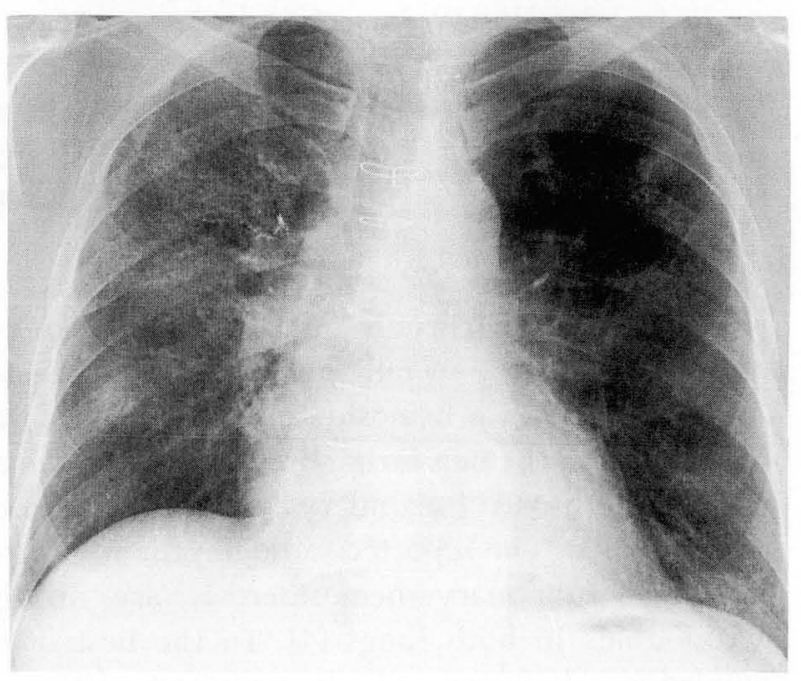

D

Fig. 1. Secondary pulmonary hemosiderosis in a 58-year-old man.

A. Initial admission chest radiograph shows bilateral patchy areas of ground-glass opacity in lower lung zone and septal thickening in bilateral costophrenic angles (arrows). Heart is slightly enlarged in size. A small, calcified nodule is seen in left upper lobe.

B. Lung window of high-resolution (1-mm collimation) CT scan obtained at ventricular level shows patchy areas of ground-glass opacity and inter-and intralobular septal thickening in both lower lobes with crazy-paving pattern.

C. Photomicrograph demonstrates multiple hemosiderin-laden macrophages (arrows) in alveolar spaces with mild interstitial fibrous thickening $(\mathrm{H}$ and $\mathrm{E}, \times 200)$.

D. Follow-up chest radiograph obtained 26 months after A shows patchy areas of ground-glass opacity in right upper and middle lung zones and left lower lung zone. Heart size is slightly enlarged. Sternotomy wires and artificial valve are also seen.

diagnosed. Histologically, multiple hemosiderin-laden macrophages were present in the alveolar spaces and there was fibrous thickening of the alveolar walls, where there was associated mild fibrotic change. The poorly-defined opacity seen on chest radiographs disappeared one month later. Due to the recurrence of coughing and shortness of breath eight months after mitral valve replacement, patients underwent followup echocardiography, and this revealed severe dysfunction of the left ventricle (ejection fraction, 30\%).
Follow-up chest radiography demonstrated patchy areas of ground-glass opacity in the right upper and middle lung zones and in left lower lung zone (Fig. 1D). HRCT scans obtained at this time showed patchy subpleural areas of ground-glass opacity and inter- and intralobular septal thickening in the right upper lobe and both lower lobes. Follow-up chest radiographs obtained one month later, when the left ventricular ejection fraction increased, showed that the extent of the opacity had decreased. 


\section{Discussion}

Idiopathic or acquired pulmonary hemosiderosis is characterized histologically by intraalveolar hemosiderin-laden macrophages, variable interstitial fibrosis, and variable type II cell hyperplasia. These findings are, however, nonspecific and can be seen in cases of pulmonary hemorrhage due to various causes.

In mitral valvular heart disease, there are several possible causes of hemoptysis. In some patients, red cells are extravasated into the alveoli and then coughed up, causing the sputum to be frankly bloody or pink and frothy. In severe and long-standing mitral stenosis, the bronchial veins may become varicose and can occasionally rupture to produce profuse hemoptysis. Pulmonary embolism is not infrequent in advanced mitral stenosis and may lead to hemoptysis. While this is thought to occur in $10 \%$ of cases involving chronic mitral stenosis, it is much less common in patients with chronic mitral regurgitation; this is because in such patients, sudden increases in left atrial pressure are less common $(5,6)$. As a result of pulmonary venous hypertension, slight to moderate intermittent hemoptysis occurs, resulting in a hemosiderosis-like picture with organization of the hemorrhage and the appearance of interstitial fibrosis (7).

Initial radiographic findings of idiopathic pulmonary hemosiderosis result from the alveolar filling process, which is due to hemorrhage. Except at both apices and bilateral costophrenic sulci, initial patchy areas of consolidation in the middle lung zone may extend to diffuse bilateral consolidation, though this is resolved within one to two weeks. Repeated hemorrhage may lead to fine nodular and reticular lesions, which persist indefinitely (8). Gates et al. (4) recently reported radiographic findings of pulmonary hemosiderosis, with multiple micronodules, in a patient with chronic heart disease. Though in our cases, the chest radiographic abnormalities were patchy areas of ground-glass opacity in the middle and lower lung zones. We therefore suggest that chest radiographic findings of early secondary pulmonary hemosiderosis may be patchy areas of consolidation or ground-glass opacity rather than the small nodules sometimes seen in patients at the advanced fibrotic stage of secondary pulmonary hemosiderosis with repeated pulmonary hemorrhage.

Cheah et al. (9) recently described the CT findings of pathologically-proven idiopathic pulmonary hemosiderosis in two patients; the predominant findings were diffuse nodules and patchy areas of ground-glass opacity. We assume that the findings of secondary pul- monary hemosiderosis seen on HRCT are similar to those of idiopathic pulmonary hemosiderosis. In our case, the abnormalities were inter- and intralobular septal thickening within patchy areas of ground-glass opacity in the form of crazy-paving pattern (10). Because parenchymal abnormalities persisted for more than a month and were as descrived above, our initial impression was subacute or chronic lung disease such as pulmonary alveolar proteinosis, rather than secondary hemosiderosis. On follow-up HRCT scans obtained 27 months later and 28 months after mitral valve replacement, the previously noted parenchymal lesions disappeared only to reappear in other areas.

CT-pathologic correlation showed that the areas of ground-glass opacity seen on CT corresponded pathologically to the areas of multiple hemosiderinladen macrophages in alveolar space and interstitial fibrous thickening. The septal thickening seen on CT was due to mild fibrotic change in the inter- and intralobular septa. Our CT findings reflect the early findings of secondary hemosiderosis with mild fibrosis, and thus, were reversible.

In conclusion, in a patient with mitral valvular heart disease, secondary pulmonary hemosiderosis in its early form can be indicated by patchy areas of ground-glass opacity with inter- or intralobular septal thickening. And these findings should not be regarded simply as indicative of the chronic form of interstitial edema or subacute or chronic interstitial lung disease. If pulmonary venous hypertension is corrected, the early form of secondary hemosiderosis may be reversible.

\section{References}

1. Sahn SH, Levine I. Pulmonary nodules associated with mitral stenosis. Arch Intern Med 1950; 85 : 483-489

2. Galloway RW, Epstein EJ, Coulshed N. Pulmonary ossific nodules in mitral valve disease. Br Heart $J 1961 ; 23: 297-307$

3. Fleming HA, Robinson CLN. Pulmonary ossification with cardiac calcification in mitral valve disease. Br Heart J 1957 ; 19 : 532-538

4. Gates J, Hartnell GG, Batten D. Pulmonary abnormalities in a patient with chronic heart disease. Acad Radiol $1997 ; 4: 398-399$

5. Hall RJC, Treasure T. Mitral valve disease. In Julian DG, Camm AJ, Fox KM, Hall RJC, Poole-Wilson PA. Diseases of the heart. London : WB Saunders, 1996: 799-852

6. Braunwald E. Valvular heart disease. In Braunwald E. A textbook of cardiovascular medicine. Philadelphia:WB Saunders, 1997: 1007-1076

7. Cortese DA. Pulmonary function in mitral stenosis. Mayo Clin Proc $1998 ; 53: 321-326$

8. Bronson SM. Idiopathic pulmonary hemosiderosis in adults: report of a case and review of the literature. AJR 1960;83:260-273

9. Cheah FK, Sheppard MN, Hansell DM. Computed tomography of diffuse pulmonary hemorrhage with pathological correlation. 
Clin Radiol $1993 ; 48: 89-93$

10. Franquet T, Gimenez A, Bordes R, Rodriguez-Arias JM, Castella J.
The crazy-paving pattern in exogenous lipoid pneumonia: CT-pathologic correlation. AJR 1998; $170: 315-317$

\section{승모판막 질환과 동반된 폐의 헤모시데린침착증 ${ }^{1}$}

1 성균관대학교 의과대학 삼성서울병원 진단방사선과

2 성균관대학교 의과대학 삼성서울병 원 진단병리과

\section{김응엽 · 김태성 · 한정호 ${ }^{2} \cdot$ 이경수}

저자들은 승모판막 질환을 가진 58세 남자 환자에서 폐생검으로 증명된 폐의 속발성 헤모시데린침착증을 경험하 여 이를 보고한다. 흉부 단순촬영에서 양폐에 반점형 분포의 간유리음영이 보였고 고해상전산화단층촬영에서는 반 점형 분포의 간유리음영과 더불어 그 내부에 이차소엽간 혹은 소엽 내부의 중격 비후 소견이 보였다. 이러한 소견은 가역적으로 폐정맥압 상승이 소실되면서 개선되었다. 